Note

\title{
Main viruses in sweet cherry plantations of Central-Western Spain
}

\author{
Rodrigo Pérez Sánchez*, Remedios Morales Corts, Pablo García Benavides, María Ángeles Gómez Sánchez
}

University of Salamanca/Faculty of Agricultural and Environmental Sciences, Av. Filiberto Villalobos, $119-$ 37007 - Salamanca - Spain.

*Corresponding author <rodrigopere@usal.es>

Edited by: Claudio Marcelo Gonçalves de Oliveira

Received April 21, 2014

Accepted July 22, 2014
ABSTRACT: Sweet cherry trees (Prunus avium L.) are susceptible to a range of diseases, but there have been no studies to date about the viral infection of sweet cherry trees in Spain. To determine the phytosanitary status of Spanish sweet cherry plantations, the incidence and leaf symptoms induced by Prune dwarf (PDV), Prunus necrotic ringspot (PNRSV) and Apple chlorotic leaf spot (ACLSV) viruses were investigated during 2009. Young leaf samples were taken from 350 sweet cherry trees, corresponding to 17 cultivars, and were analysed by double antibody sandwich enzyme-linked immunosorbent assay (DAS-ELISA). To associate the leaf symptoms with the virus, 50 mature leaves from each infected tree were visually inspected during the summer. The ELISA results revealed that $72 \%$ of sweet cherry trees were infected by at least one of the viruses. PDV occurred in all sampled cultivars and presented the highest infection rate, followed by ACLSV and PNRSV. A high number of trees showed asymptomatic, in both single and mixed infections. The leaf symptoms associated with the viruses involved generalized chlorosis around the midvein (PDV), chlorotic and dark brown necrotic ringspots on both secondary veins and intervein regions (PNRSV), chlorotic and reddish necrotic ringspots (ACLSV) and generalized interveinal chlorosis (PDV-PNRSV).

Keywords: Prunus avium, ELISA, stone fruit, symptoms

\section{Introduction}

Sweet cherry trees (Prunus avium L.) are susceptible to a range of pests and diseases, and this increases the challenge of profitable production. Moreover, grafting is the most common asexual method for propagating cherry trees and one of the important features for the maintaining and spreading of diseases. Among them, viral diseases are of special relevance because the trees are often asymptomatic and viruses cause significant economic loss through lower yields and reduced quality of plant products (Cembali et al., 2003). Some of the most widespread viruses affecting sweet cherry trees and other Рrunus species include Prune dwarf virus (PDV), Prunus necrotic ringspot virus (PNRSV) and Apple chlorotic leafspot virus (ACLSV).

PDV and PNRSV belong to the genus Ilarvirus (Bromoviridae) which are composed of a tripartite genome and isometric to bacilliform particles (Fauquet et al., 2005; Pallás et al., 2012, 2013). PDV-infected trees often remain symptomless but necrotic and chlorotic spots on cherry leaves have also been reported (Massart et al., 2008). Sweet cherry trees infected by PNRSV exhibit an array of symptoms ranging from none to a severe rugose mosaic disease, depending upon the virus strain or isolate (Howell and Mink, 1988). These Ilarviruses are transmitted by mechanical inoculation, graft, pollen and seed (Matić et al., 2008a). Finally, ACLSV is the type species of the genus Trichovirus (Betaflexiviridae) and is composed of a flexuous filamentous particle containing a positive-sense, singlestranded RNA (Martelli et al., 2007; Al Rwahnih et al., 2004). Infected trees are normally symptomless but severe graft incompatibilities in nurseries and deformation and discoloration (russet rings, pox and necrotic spots) in sweet cherries have also been reported (Rana et al., 2011). ACLSV is transmitted by mechanical inoculation and grafting (Martelli et al., 2007).

Many studies addressing the PDV, PNRSV and ACLSV viruses in sweet cherry trees have been reported in other regions around the world (Al Rwahnih et al., 2001; Bouani et al., 2004; Boyé and Gentit, 1998; Cağlayan et al., 2008; Di Terlizzi, 1998; Mandic et al., 2007; Matić et al., 2008b; Michelutti et al., 2005; Milusheva and Borisova, 2005; Oliver et al., 2009; Rouag et al., 2008; Sipahioglu and Baloglu, 2006; Sipahioglu et al., 1999; Suchá and Svobodová, 2010). However, there have been no studies about the presence, distribution or symptoms caused by these three viruses in sweet cherry trees in Spain. Therefore, this paper reports the incidence of PDV, PNRSV, and ACLSV in P. avium trees from the main Spanish sweet cherry-producing area, Jerte and its neighbouring regions, and the symptoms induced by these viruses.

\section{Materials and Methods}

\section{Sources of plants}

Field inspections and sample collections were carried out in the main Spanish sweet cherry-producing area, Jerte and its neighbouring regions, during 2009. A total of 39 sweet cherry orchards located in the regions known as

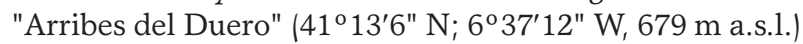
and "Sierra de Francia" $\left(40^{\circ} 27^{\prime} 52^{\prime \prime}\right.$ N; $6^{\circ} 3^{\prime} 43^{\prime \prime}$ W, 630 m a.s.l.) were visited. Five samples of young leaves were collected from the yearly flush at the tip of lower branches from each of the 350 sweet cherry trees. The cultivars sampled from April to June were: "Ambrunés", "Burlat", 
"Del País", "Del País Temprana", "Early Bigi", "Garnet", "Jarandilla", "Lamper", "Marvin", "Mollar", "Monzón", "Moracha", "Pico Negro", "Ramón Oliva", "Starking", "Summer Charm", and "Sunburst".

Double antibody sandwich enzyme-linked immunosorbent assay (DAS-ELISA) method

The samples were assayed by DAS-ELISA, according to Clark and Adams (1977) and Cambra et al. (1994). Commercial antisera for PDV, PNRSV and ACLSV (Bioreba, Switzerland) were used as described by the manufacturer. The samples were considered positive for the viruses when absorbance at $405 \mathrm{~nm}$ exceeded two and a half times the absorbance value of the healthy.

\section{Visual evaluation of leaf symptoms}

Fifty adult leaves from each infected sweet cherry tree were visually inspected in the field and the laboratory during the summer with the intent of detecting the main symptoms induced by PDV, PNRSV, and ACLSV, both single and mixed infections.

\section{Results and Discussion}

\section{Serological evaluation}

A high percentage of sweet cherry trees $(72 \%)$ were infected by at least one virus (Table 1). Similar overall mean infection rates were also reported for these three viruses by Mandic et al. (2007) in a sweet cherry collection in Serbia and Di Terlizzi (1998) in cherry trees from Italy, $63 \%$ and $65 \%$, respectively. "Ambrunés", "Mollar", "Moracha", and "Pico Negro" cultivars had the highest number of infected trees (between $94 \%$ and $100 \%$ ). These cultivars have been grown traditionally in Jerte and its neighbouring regions for hundreds of years (Pérez-Sánchez et al., 2008) and have not undergone any health improvement program. On the other hand, less than $50 \%$ of the trees from the improved sweet cherry, "Marvin", "Garnet", "Early Bigi", and "Summer Charm", were infected. These cultivars were introduced in Spain from the United States, France, and Canada during the sweet cherry-breeding programs in the late twentieth century. López-Corrales et al. (2014) also stressed the need to carry out a program to improve the health of traditional Spanish cultivars of sweet cherry.

The most abundant virus was PDV, infecting all cultivars. It was detected in $87 \%$ of the infected sweet cherry trees. High PDV infection rates in cherry trees were also reported by Al Rwahnih et al. (2001) in Jordan, Suchá and Svobodová (2010) in the Czech Republic, Di Terlizzi (1998) in Italy, Sipahioglu et al. (1999) in Turkey, Mandic et al. (2007) in Serbia, Rouag et al. (2008) in Algeria and Michelutti et al. (2005) in Canada.

PNRSV and ACLSV were not widespread in sweet cherry crops and the percentages among the infected plants were low (18\% and $22 \%$, respectively). Low percentages of PNRSV and/or ACLSV infections were detected by Suchá and Svobodová (2010), Oliver et al. (2009), Mandic et al. (2007), and Myrta and Savino (2008) in sweet cherry and cherry. The traditional cultivars "Jarandilla", "Mollar", "Moracha", and "Pico Negro" showed the highest ACLSV infection rates (Table 1). Eight cultivars were ACLSV-free: "Del País", "Del País Temprana", "Garnet", "Lamper", "Marvin", "Monzón", "Ramón Oliva", and "Starking". Thus, ACLSV appears to have a limited distribution among sweet cherry-growing area. Moreover, in other countries such as Algeria, Jor-

Table 1 - Relative incidence of Prune dwarf (PDV), Prunus necrotic ringspot (PNRSV) and Apple chlorotic leaf spot (ACLSV) in sweet cherry cultivars in Jerte (Spain) and its neighbouring regions.

\begin{tabular}{|c|c|c|c|c|c|c|c|c|c|}
\hline \multirow[t]{2}{*}{ Cultivar } & \multirow[t]{2}{*}{ Tested trees } & \multicolumn{2}{|c|}{ Infected trees } & \multicolumn{2}{|c|}{ PDV } & \multicolumn{2}{|c|}{ PNRSV } & \multicolumn{2}{|c|}{ ACLSV } \\
\hline & & No. & $\%$ & No. & $\%$ & No. & $\%$ & No. & $\%$ \\
\hline Ambrunés & 20 & 20 & 100 & 18 & 90 & 8 & 40 & 4 & 20 \\
\hline Burlat & 68 & 44 & 65 & 32 & 47 & 4 & 6 & 14 & 21 \\
\hline Del País & 14 & 8 & 57 & 8 & 57 & 0 & 0 & 0 & 0 \\
\hline Del País Temp. & 14 & 10 & 71 & 10 & 71 & 0 & 0 & 0 & 0 \\
\hline Early Bigi & 14 & 6 & 43 & 6 & 43 & 2 & 14 & 2 & 14 \\
\hline Garnet & 16 & 8 & 50 & 8 & 50 & 0 & 0 & 0 & 0 \\
\hline Jarandilla & 16 & 12 & 75 & 8 & 50 & 2 & 13 & 6 & 38 \\
\hline Lamper & 24 & 16 & 67 & 16 & 67 & 2 & 8 & 0 & 0 \\
\hline Marvin & 16 & 8 & 50 & 8 & 50 & 0 & 0 & 0 & 0 \\
\hline Mollar & 14 & 14 & 100 & 10 & 71 & 6 & 43 & 6 & 43 \\
\hline Monzón & 22 & 16 & 73 & 16 & 73 & 8 & 36 & 0 & 0 \\
\hline Moracha & 14 & 14 & 100 & 12 & 86 & 2 & 14 & 6 & 43 \\
\hline Pico Negro & 32 & 30 & 94 & 26 & 81 & 6 & 19 & 14 & 44 \\
\hline Ramón Oliva & 18 & 16 & 89 & 14 & 78 & 4 & 22 & 0 & 0 \\
\hline Starking & 16 & 12 & 75 & 12 & 75 & 0 & 0 & 0 & 0 \\
\hline Summer Charm & 16 & 6 & 38 & 4 & 25 & 0 & 0 & 2 & 13 \\
\hline Sunburst & 16 & 12 & 75 & 10 & 63 & 2 & 13 & 2 & 13 \\
\hline TOTAL & 350 & 252 & 72 & 218 & 62 & 46 & 13 & 56 & 16 \\
\hline
\end{tabular}


dan and Morocco, no infection by ACLSV in cherry trees has been reported (Rouag et al., 2008; Al Rwahnih et al., 2001; Bouani et al., 2004).

Mixed infections involving two or three virus species were detected. PDV and ACLSV were the viruses that most frequently appeared in combination, representing $12 \%$ of infected sweet cherry trees, followed by PDV and PNRSV (10 \%). However, Mandic et al. (2007) and Çevik et al. (2011) reported that this latter viral combination was the most frequent in sweet cherry trees in Serbia and Turkey, respectively. Mixed infections of PDV-PNRSV-ACLSV, and PNRSV-ACLSV were rare, representing $2 \%$ and $1 \%$ of infected-sweet cherry trees, respectively. Sipahioglu et al. (1999) and Mandic et al. (2007) also reported low infection rates for mixed infections involving PNRSV-ACLSV in cherry trees. While "Del País", "Del País Temprana", "Garnet", "Marvin", "Starking", and "Summer Charm" were the only cultivars that did not present mixed infections, "Pico Negro" and "Ambrunés" showed the highest number of sweet cherry trees with mixed infections, $6 \%$ and $3 \%$ of infected trees, respectively. Moreover, "Pico Negro" was the only cultivar infected by PNRSV and ACLSV simultaneously.

\section{Visual evaluation of leaf symptoms}

A high number of trees, ranging from $65 \%$ to 100 $\%$, showed asymptomatic, in both single and mixed infections. PDV induced symptoms in a large number of trees (35\%). Mature leaves showed a generalized chlorosis around the midvein, mainly near the basis of the leaf (Figure 1A). Smith et al. (1988) reported that PDV-induced symptoms, such as chlorotic spots, rings and diffuse mottling, appeared on leaves that were almost completely expanded. They also reported that PDV-infected sweet cherry trees often remain symptomless in the following years. "Moracha", "Ambrunés", "Del País" group, "Jarandilla", and "Mollar" presented the highest number of trees with symptoms induced by PDV, while "Early Bigi" remained symptomless.

Twenty-one percent of PNRSV-infected sweet cherry trees showed chlorotic ringspots that evolved to dark brown necrotic areas in both secondary veins and interveinal regions of the leaf (Figure 1B). Remarkably, the leaves with symptoms of PNRSV infection were not completely expanded, in contrast to those affected by PDV. Smith et al. (1988) also observed chlorotic or necrotic spots on the leaves of sweet cherry trees infected by PNRSV, but the centres of these necrotic spots often disappeared, affording a shot-hole effect. "Mollar", "Pico Negro", and "Burlat" were the only cultivars with leaf symptoms in PNRSV infection. Otherwise, "Ambrunés", "Ramón Oliva", and "Sunburst" remained asymptomatic when infected by PNRSV.

ACLSV infection was observed in $23 \%$ of symptomatic trees. The leaves displayed chlorotic ringspots that evolved to reddish necrotic areas, with more intensely coloured edges than the centres (Figure 1C). Smith et al. (1988) noted that ACLSV infection induced a sunken mot-

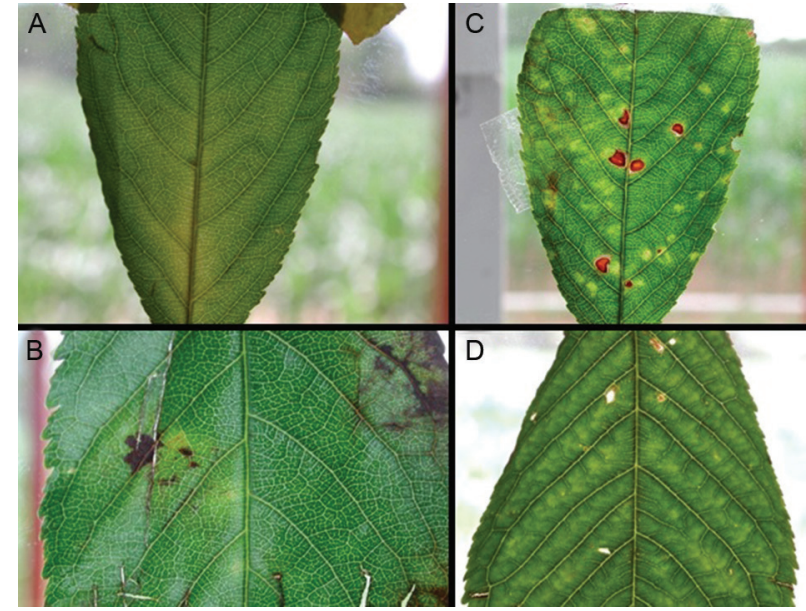

Figure 1 - Leaf symptoms associated with single or mixed viral infections; (A) Generalized chlorosis around the midvein due to PDV; (B) Chlorotic and dark-brown necrotic ringspots induced by PNRSV; (C) Chlorotic and reddish necrotic ringspots induced by ACLSV; (D) Generalized interveinal chlorosis due to PDV-PNRSV mixed infection.

tle on the peach leaves. Despite this, no data are available concerning leaf symptoms induced by the virus in sweet cherry trees. Infection induced by ACLSV was symptomatic in "Pico Negro", "Moracha", "Jarandilla", and "Burlat" and asymptomatic in "Mollar" and "Sammer Charm".

The few symptomatic sweet cherry trees $(16 \%)$ that were detected with mixed infection were victims of PDV-PNRSV. This mixed infection induced in "Jarandilla", "Ambrunés", "Mollar", and "Monzón" leaves generalized interveinal chlorosis (Figure 1D). This mixed viral infection can increase damage to sweet cherry trees (Smith et al., 1988). Nonetheless, there are no data in the literature about the leaf symptoms shown by sweet cherry trees with the PDV-PNRSV mixed infection. "Early Bigi", "Lamper", and "Ramón Oliva" with this mixed viral infection exhibit no symptoms. All sweet cherry trees affected by the rest of mixed infections (PDV-ACLSV, PNRSV-ACLSV, and PDV-PNRSV-ACLSV) remained asymptomatic.

As a conclusion, it was observed that sweet cherry trees are widely affected by both single and mixed infections involving the three viruses studied; a health-improvement program, such as in vitro regeneration, should be designed in order to ensure the future of the sweet cherry plantations of Central-Western Spain.

\section{Acknowledgements}

The authors thank growers of the main Spanish sweet cherry-producing area ("Jerte and neighbouring regions") for their major contribution to the work. Financial support for this research was provided by the Biodiversity Foundation of the Spanish Ministry of Environment and Rural and Marine Affairs (MARM) and the Spanish Federation of Municipalities and Provinces (FEMP). 


\section{References}

Al Rwahnih, M.; Myrta, A.; Abou-Ghanem, N.; Di Terlizzi, B.; Savino, V. 2001. Viruses and viroids of stone fruits in Jordan. OEPP/EPPO Bulletin 31: 95-98.

Al Rwahnih, M.; Turturo, C.; Minafra, A.; Saldarelli, P.; Myrta, A.; Pallás, V.; Savino, V. 2004. Molecular variability of Apple chlorotic leaf spot virus in different host and geographical regions. Journal of Plant Pathology 86: 117-122.

Bouani, A.; Al Rwahnih, M.; Abou Ghanem-Sabanadzovic, N.; Alami, I.; Zemzami, M.; Myrta, A.; Savino, V. 2004. A preliminary account of the sanitary status of stone-fruit trees in Morocco. OEPP/EPPO Bulletin 34: 399-402.

Boyé, R.; Gentit, P. 1998. Sanitary status of stone fruit industry in the Mediterranean countries: France. p. 47-49. In: Di Terlizzi, B.; Myrta, A.; Savino, V., eds. Stone fruit viruses and certification in the Mediterranean countries: problems and prospects. CIHEAM, Bari, Italy. (Options Méditerranéennes, Série B,19).

Cağlayan, K.; Gazel, M.; Ulubaş, C. 2008. Phytosanitary status of cherry trees in the east Mediterranean region of Turkey. Acta Horticulturae 795: 919-924.

Cambra, M.; Asensio, M.; Gorris, M.T.; Pérez, E.; Camarasa, E.; García, J.A.; Moya, J.J.; López-Abella, D.; Vela, C.; Sanz, A. 1994. Detection of plum pox potyvirus using monoclonal antibodies to structural and non-structural proteins. EPPO Bulletin 24: 569-577.

Cembali, T.; Folwell, R.J.; Wandschneider, P.; Eastwell, K.C.; Howell, W.E. 2003. Economic implications of a virus prevention program in deciduous tree fruits in the US. Crop Protection 22: 1149-1156.

Çevik, B.; Yardimci, N.; Çulal-Kiliç, H. 2011. Detection of viruses infecting stone fruits in western Mediterranean region of Turkey. Plant Pathology Journal 27: 44-52.

Clark, M.F.; Adams, A.N. 1977. Characteristics of the microplate method of enzyme-linked immunosorbent as-say for the detection of plant viruses. Journal of General Virology 34: 475-483.

Di Terlizzi, B. 1998. Sanitary status of stone fruit industry in the Mediterranean countries: Italy. p. 53-56. In: Di Terlizzi, B.; Myrta, A.; Savino, V., eds. Stone fruit viruses and certification in the Mediterranean countries: problems and prospects. CIHEAM, Bari, Italy. (Options Méditerranéennes, Série B, 19).

Fauquet, C.M.; Mayo, M.A.; Maniloff, J.; Desselberger, U.; Ball, L.A. 2005. Virus taxonomy: Eighth Report of the International Committee on Taxonomy of Viruses. Elsevier Academic Press, London, UK.

López-Corrales, M.; Manzano, M.A.; Pérez, F.; Serradilla, M.J.; Alarcón, M.V. 2014. Differences of in vitro thermotolerance to high temperatures in autochthonous sweet cherry varieties from the Jerte Valley (Spain). Acta Horticulturae 1020: 229-232

Howell, W.E.; Mink, G.I. 1988. Natural spread of cherry rugose mosaic disease and two Prunus necrotic ringspot virus biotypes in a Central Washington sweet cherry orchard. Plant Disease 72: 636-640.

Mandic, B.; Matić, S.; Al Rwahnih, M.; Myrta, A. 2007. Viruses of sweet and sour cherry in Serbia. Journal of Plant Pathology 89: 103-108.

Martelli, G.P.; Adams, M.J.; Kreuze, J.F.; Dolja, V.V. 2007. Family Flexiviridae: a case study in virion and genome plasticity. Annual Review of Phytopathology 45: 73-100.
Massart, S.; Brostaux, Y.; Barbarossa, L.; César, V.; Cieslinska, M.; Dutrecq, O.; Fonseca, F.; Guillem, R.; Laviña, A.; Olmos, A.; Steyer, S.; Wetzel, T.; Kummert, J.; Jijakli, M.H. 2008. Interlaboratory evaluation of a duplex RT-PCR method using crude extracts for the simultaneous detection of Prune dwarf virus and Prunus necrotic ringspot virus. European Journal of Plant Pathology 122: 539-547.

Matić, S.; Sánchez-Navarro, J.A.; Mandic, B.; Myrta, A.; Pallás, V. 2008a. Tracking three Ilarviruses in stone fruit trees throughout the year by Elisa and tissue-printing hybridization. Journal of Plant Pathology 90: 137-141.

Matić, S.; Al Rwahnih, M.; Myrta, A.; Durić, G. 2008b. Viruses of stone fruits in Bosnia and Herzegovina. Acta Horticulturae 781: 71-74.

Michelutti, R.; Myrta, A.; Pallás, V. 2005. A preliminary account on the sanitary status of stone fruits at the Clonal Genebank in Harrow, Canada. Phytopathologia Mediterranea 44: 71-74.

Milusheva, S.A.; Borisova, A.Z. 2005. The incidence of Prunus necrotic ringspot and Prune dwarf viruses in Prunus species in South Bulgaria. Biotechnology and Biotechnological Equipment 19: 42-45.

Myrta, A.; Savino, V. 2008. Virus and virus-like diseases of cherry in the Mediterranean region. Acta Horticulturae 795: 891-896.

Oliver, J.E.; Freer, J.; Andersen, R.L.; Cox, K.D.; Robinson, T.L.; Fuchs, M. 2009. Genetic diversity of Prunus necrotic ringspot virus isolates within a cherry orchard in New York. Plant Disease 93: 599-606.

Pallás, V.; Aparicio, F.; Herranz, M.C.; Amari, K.; Sánchez-Pina, M.A.; Myrta, A.; Sánchez-Navarro, J.A. 2012. Ilarviruses of Prunus spp.: a continued concern for fruit trees. Phytopathology 102: 1108-1120.

Pallás, V.; Aparicio, F.; Herranz, M.C.; Sánchez-Navarro, J.A.; Scott, S.W. 2013. The molecular biology of ilarviruses. Advances in Virus Research 87: 139-181.

Pérez-Sánchez, R.; Gómez-Sánchez, M.A.; Morales-Corts, R. 2008. Agromorphological characterization of traditional Spanish sweet cherry (Prunus avium L.), sour cherry (Prunus cerasus L.) and duke cherry (Prunus x gondouinii Rehd.) cultivars. Spanish Journal of Agricultural Research 6: 42-55.

Rana, T.; Chandel, V.; Hallan, V.; Zaidi, A.A. 2011. Expression of recombinant Apple chlorotic leaf spot virus coat protein in heterologous system: production and use in immunodiagnosis. Journal of Plant Biochemistry and Biotechnology 20: 138-141.

Rouag, N.; Guechi, A.; Matic, S.; Myrta, A. 2008. Viruses and viroids of stone fruits in Algeria. Journal of Plant Pathology 90: 393-395.

Sipahioglu, H.M.; Baloglu, S. 2006. The incidence of Prunus necrotic ringspot (PNRSV) and Apple chlorotic leafspot (ACLSV) viruses on stone fruits grown in East Anatolia region of Turkey. Acta Horticulturae 701: 469-472.

Sipahioglu, H.M.; Myrta, A.; Abou-Ghanem, N.; Di Terlizzi, B.; Savino, V. 1999. Sanitary status of stone-fruit trees in East Anatolia (Turkey) with particular reference to apricot. OEPP/ EPPO Bulletin 29: 439-442.

Smith, I.M.; Dunez, J.; Phillips, D.H.; Lelliott, R.A.; Archer, S.A. 1988. European handbook of plant diseases. Blackwell Scientific, Oxford, UK.

Suchá, J.; Svobodová, L. 2010. Incidence of Prune dwarf virus and Prunus necrotic ring spot virus in orchards of sweet cherry and sour cherry in the Czech Republic. Horticultural Science 37: 118-120. 